\title{
THE BASIC LAW OF THE STATE: LEGAL CONTENT
}

\section{Bielov D. M.}

\section{INTRODUCTION}

Constitutionalism as a politico-legal category and doctrinal learning appears after the emergence and establishment of the constitution of the state in the modern sense of this term. It is inseparable and directly derived from the constitution of the state. Although not always the fact of the existence of a constitution automatically means the emergence of a particular model of constitutionalism. However, without the appearance (availability) of the constitution itself (in the broad sense of this notion), there is no need to talk about constitutionalism. The substantive basis, the very essence of constitutionalism, according to V. Shapoval, is expressed by the formula: "constitutional-legal norm + practice of its implementation"". Therefore, a bit strange, in our opinion, when in certain writings, including monographs, there are such statements as "ancient", "medieval", "totalitarian" or "Soviet constitutionalism", since at that time the constitution as such (in the modern understanding of this concept) simply did not exist. However, it was precisely in previous times that, in fact, the foundations of the future phenomenon - constitutionalism were laid $^{2}$.

The Constitution of Ukraine is a part of the national legal system, its core, acts as "coordinator of the system of legislation" . But, as Yu. Tykhomyrov notes, despite the fact that the Constitution, as if is in the middle of the legal array, its influence is not limited to the link "act-act". All elements of the legal system, in turn, also affect the constitution ${ }^{4}$.

On the one hand, the Constitution is a kind of construction, on which practically all legislation is being built ${ }^{5}$. It is the Constitution that defines the nature of the current legislation, the process of law-making - determines, which basic acts are adopted by various bodies, their names, legal force, the process and procedure for the adoption of laws ${ }^{6}$. The development

${ }^{1}$ В.М. Шаповал. Конституційне право зарубіжних країн: підручник. Київ: АртЕк, Вища шк., 1997. Р. 135.

${ }^{2}$ П.Б. Стецюк. Основи теорії конституції та конституціоналізму. Частина перша: Посібник для студентів. Львів: Астролябія, 2004. Р. 98.

${ }^{3}$ И.М. Степанов. Конституция и политика. Москва: Изд-во Наука, 1984. Р. 40.

${ }^{4}$ Ю.А.Тихомиров, И.В. Котелевская. Правовые акты: Учебно-практическое и справочное пособие. Москва: Юринформцентр, 1999. Р. 15.

${ }_{5}^{5}$ О.В. Оніщенко. Конституція України як основне джерело конституційного права України. Київ: Консум, 2005. Р. 211.

${ }^{6}$ Е.И. Козлова, О.Е. Кутафин. Конституционное право России. Москва: Юристъ, 2003. P. 87. 
of legislation is possible only within the parameters enshrined in the Constitution, which serves as an important condition for ensuring its unity, internal coherence ${ }^{7}$. As S. Shevchuk notes, the constitutional norms are formulated in the form of an open text, and, consequently, constitute "empty vessels", which must be filled with a specific content ${ }^{8}$. Therefore, the adoption of a new constitution in the state, as a rule, causes significant changes and updates to current legislation. Ukraine is no exception. Although, as V. Opryshko notes, "the current legislation does not yet fit into the legal framework defined by the Constitution of Ukraine" ${ }^{\text {. }}$

However, the notion of a constitution cannot be disclosed to the full extent without clarifying the question about not only its legal but also sociopolitical nature.

\section{The constitution of the state in the context of its functions}

According to M. Savchyn, the supremacy of the constitution must be supported by certain institutional and procedural guarantees. Only in their totality, they determine the nature of the constitution. Institutional and procedural guarantees define certain criteria for the quality of legislation, administrative and judicial practice. Thus, the nature of the constitution and constitutional order are conditioned by the problem of statics and the dynamics of constitutional matter. The definition of the nature of the constitution is also influenced by the social environment since real constitutional relationships are determined by a certain type of society, civilization in general. The nature of the constitution is influenced by the legal tradition, which is based on the paradigm of constitutionalism, constitutional consciousness and culture, national traditions of government, the system of social values. A diversity of approaches to defining the nature of the constitution determines how these components are combined in the process of drafting the constitution and building a constitutional order ${ }^{10}$.

The Constitution fulfils the function of legitimizing public order. Therefore, in the form of constitutional principles, democratic access to positions is determined through democratic elections and the fundamental principles of separation of powers, as well as the limitation of power, which are carried out mainly through legal guarantees of human rights and freedoms ${ }^{11}$. From the institutional point of view, the constitution is embodied

${ }^{7}$ В.О. Лучин. Конституция Российской Федерации. Проблемы реализации. Москва: Юнити-Дана, 2002. Р. 79.

${ }^{8}$ С. Шевчук. Основи конституційної юриспруденції: навчальний посібник. Харків: Консум, 2002. Р. 7.

${ }^{9}$ В.Ф. Опришко. Конституція України - основа системи національного законодавства. Київ: Видавничий Дім «Юридична книга», 2000. Р. 118.

10 М.В. Савчин. Конституціоналізм і природа конституції: монографія. Ужгород: Поліграфцентр «Ліра», 2009. Р. 256.

${ }^{11}$ Р. Циппеліус. Філософія права. Київ: Тандем, 2000. Р. 204-205. 
in ensuring the consolidation of democracy, representation of the people through free and periodic elections, parliamentary regime, and judicial constitutional control.

In the normative sense, the constitution includes both the provisions that contain specific regulations, as well as the provisions that determine the general legal principles of intervention in private life. Accordingly, the constitution has both a vertical and a horizontal structure. The vertical structure of the constitution relates to its own requirements, horizontal one defines a set of principles of law (provisions-principles), which operates both in the sphere of public and private law. Thus, the constitution in the normative sense extends to the sphere of public and private law ${ }^{12}$.

In its content, the constitution expresses: a) a public consensus on social values provided by legal protection; b) ways of implementing democratic procedures and control of the people over the public authority; c) legitimation of public authority; d) limits of interference of public authority in the private autonomy of a person; e) legal mechanism of international cooperation of the state. Thus, the constitution in its content is a certain type of social order that is based on the definition of the legitimate framework of government in order to ensure the public good (balance of public and private interests).

In the formally-legal sense, the constitution is understood as the Basic Law, which has a constitutive character and has the rule of law. One should agree with M. Savchyn that, as a normative legal act, the Constitution of Ukraine has the following properties ${ }^{13}$ :

a) constitutive nature - the constitution is an act of the constituent power; hence the constitution cannot be considered as a result of the legislative process of the parliament, which is actually established by the constitution and bound by its requirements. The Constitution, therefore, sets the foundations for the organization of society and the state, defines the foundations of the legal status of a person, the content and directions of activities of state authorities and local self-government, foundations of activities of institutes of the political system, and principles of the democratic system in the country.

Since people in a democratic state are recognized as the bearer of sovereignty and the only source of power, only they possess its highest manifestation - the constituent power. The content of the latter is the right to adopt a constitution and, with the help of it, to create the foundations of a social and state system that chooses one or another people for themselves. Only the constituent government can change, in the most radical way, foundations of the structure of society and the state. The whole history of the

\footnotetext{
${ }^{12}$ М.В. Савчин. Конституціоналізм. Р. 256.

${ }^{13}$ Ibid, p. 259.
} 
constitutional development of both our country and foreign countries serves as a confirmation. Using constitutions, fundamental changes in the entire social system obtained the legitimacy.

It is the recognition of the constitutive nature of the constitution that the special order of its adoption, its supremacy, its role in the entire legal system of the state, the non-contradiction of the constitution for all the powers established by it, including for the legislative, are based.

In the foreign science of constitutional law, the concept, according to which the difference between the constituent power and the authority is established, is quite broadly presented. And in Germany, it received a direct expression in the constitution itself. In its preamble, it is said: "[...] the German people, by virtue of their constituent power, have created the Basic Law”.

The constitutive nature of the constitution is manifested also in the fact that its prescriptions act as the first principles are primary. This means that there are no legal restrictions to establish the provisions of the constitution. There can be no such legal provision that could not be included in the constitution on the grounds that it does not correspond to any legal act of the given state. Yes, laws in Ukraine cannot contradict the Constitution. Of course, from this does not follow the conclusion that the content of the constitutional provisions is arbitrarily determined that any provision may be included in the constitution;

b) the main law - the constitution is the core of the legal system, laws and regulations are developed and adopted on its basis, it lays the program, the general direction of law-making work in the state, consolidates the system of sources of national law;

c) the highest legal force - any other normative act can distort the content of the constitution, it creates such an order when justice and law should not diverge. The Constitution of Ukraine has the highest position among rules and regulations, which should not contradict it, but conform to its basic principles and spirit.

In its Decision № 2-в/99 on 02.06.1999, the Constitutional Court interpreted the principle of the supreme legal force of the constitution in the following way: "One of the most important conditions for the definiteness of relations between a citizen and a state, the guarantee of the principle of inviolability of human rights and freedoms enshrined in Article 21 of the Constitution of Ukraine is the stability of the Constitution, which, in addition to other factors, is largely determined by the legal content of the Basic Law. The presence in the Constitution of Ukraine of too detailed provisions, which place is in the current legislation, will give rise to the need for frequent changes to it, which will negatively affect the stability of the Basic Law";

d) the horizontal effect - the constitution equally is the basis for the rules of public and private law; such a normative influence of the constitution on 
the legal system of the country is realized through the specification of constitutional principles and human rights and freedoms at the level of current legislation and constitutional jurisprudence;

e) the supremacy of the Constitution regarding international treaties submitted to the parliament for the ratification procedure; this provision also applies to international treaties, duly ratified by the Parliament;

f) direct action of constitutional norms means the duty of state authorities and local self-government bodies, their officials to apply directly provisions of the Constitution in the presence of gaps in law or in the event of a conflict between constitutional provisions and provisions of law; if it is impossible to eliminate such a contradiction during the course of law enforcement, then such a conflict is finally resolved by the Constitutional Court of Ukraine;

g) special procedure for adoption - the constitution in the modern sense of this concept is an act that is usually adopted by the people or on behalf of the people. Characteristically, the emergence in the XVII century of the very idea of the need for such an act as a constitution was associated precisely with this feature.

The demand imposed by the bourgeoisie to restrict the rights of the king and feudal lords to protect their liberties could only be secured through the adoption of an act of supreme authority that embodies the will of the entire nation, of all the people. Thus in an unrealizable in practice "People's Agreement" project of Cromwell in 1653, the condition for signing it by all the people was provided. The same requirement was put forward later by J. Russo. He believed that the constitution requires the consent of all citizens. It should be the result of a unanimous decision, signed by all citizens, and opponents of the constitution should be considered foreigners among citizens.

This essential feature of the constitution is still recognized as dominant in constitutional theory and practice. It is no coincidence that the constitutions of most democratic states of the world begin with the words: "We, the people [...] accept (proclaim, establish, etc.) this constitution”.

In Soviet constitutions, this formula was first restored in the Constitution of the USSR in 1977, the Constitution of the RSFSR in 1978. Thus, in the preamble to the Constitution of 1978, it was written: "The people of the Russian Soviet Federative Socialist Republic ... accept and proclaim this Constitution" 14 .

The idea of the people's involvement in the adoption of the constitution could not be ignored even under a totalitarian regime. Then it was expressed in a nationwide discussion of the draft Constitution of the USSR in 1936, which was held for six months with the widest scope and designed to

${ }^{14}$ Конституция (Основной Закон) РРФСР 1978 года, Известия ЦИК Союза ССР и ВЦИК 1978, № 121, 8 июня. 
"sanctify" the Basic Law by the will of the people. The Soviet Union Constitution of 1977 was also subject to a nationwide discussion ${ }^{15}$.

\section{The latest constitutions in the history of World Constitutionalism}

V. Shapoval argues that it is possible to identify common features by the content of the newest constitutions. Firstly, they reflect the relatively large role of the state in the economic sphere; consolidate economic function of the state. Secondly, according to the content of the relevant basic laws, the person has been recognized as a priority in its relations with the state. The latest constitutions, of course, contain meaningful provisions on rights and freedoms and fix a number of socio-economic rights. At the same time, quite wide guarantees of the enforcement of rights and freedoms are established and new mechanisms for their protection (ombudsman, constitutional complaint, etc.) are created. Thirdly, the newest major laws represent to a greater extent provisions of social orientation, although their meaning and purpose are different. Fourthly, relations that arise within the political system of society outside the state organization became the subject of constitutional regulation. This primarily concerns activities of political parties in their interactions with the state mechanism. Finally, fifthly, the sign of the newest constitutions is the presence in their texts of the provisions on foreign political activities of the state and the relation of national and international law ${ }^{16}$.

Characteristic features of the newest constitutions in one way or another characterize also the basic laws adopted in the post-socialist and post-Soviet countries in the 90 years of the last century. It is they that are sometimes distinguished as the constitutions of the fourth "wave" since they were introduced and operate in other socio-political conditions than the constitutions of the third "wave". The current Basic Law of Ukraine also belongs to the constitutions of the fourth "wave"17.

In the main laws of the fourth wave, the importance of human rights and their guarantees for the society and the state is often emphasized to a greater extent. Almost all of them define the state as legal and social, state political, economic, and ideological pluralism, fix certain provisions of the naturallegal content. Concerning the construction of the state mechanism for the authors of the main laws adopted in the post-socialist and post-Soviet countries, in most cases, the French Constitution of 1958, which began the practice of a mixed republican form of government, served as a model ${ }^{18}$.

\footnotetext{
${ }^{15}$ Ю.П. Еременко. Советская Конституция и законность. Саратов: Изд-во СГУ, 1982. P. 112 .

${ }^{16}$ В. Шаповал. Феномен конституции в контексте отечественной политико-правовой «мифологии», «Зеркало недели», 29 (2008), 9 August. Р. 4.

${ }_{17}$ Ю.Н. Тодыка. Конституция Украины: проблемы теории и практики. Харків: Факт, 2000. P. 78.

${ }^{18}$ В. Шаповал. Феномен конституции. Р. 4. 
The history of world constitutionalism involves the classification of constitutions as instrumental and social. Instrumental constitutions are defined as those whose content is primarily focused on establishing the status of key parts of the state machinery. Provisions on the status of the individual play a minor role in these constitutions and the question of social being is generally outside the scope of their regulation. In contrast to the instrumental constitutions, some provisions of social basic laws are addressed to society; in particular, they confirm social and economic rights ${ }^{19}$.

To the greatest extent, provisions of the actual social direction are presented in the latest basic laws, although, as noted, the meaning, content, and purpose of these provisions are different. In some cases, the constitution proclaimed the social and economic guidelines (tasks) of the state or even declared the need for reforms in the relevant spheres, established mechanisms for the interaction of state institutions with "non-state" components of the political system of society. It is these basic laws, which are defined as social. In other cases, everything comes to nothing more than the attributive use of certain terms and providing social sound to texts of laws ${ }^{20}$.

According to V. Shapoval, the socialization of the newest constitutions should be distinguished from "sociologization" of the Soviet constitutions, which were considered the basic laws of society. The texts of these constitutions were filled with non-legal abstractions, filled with terminology, which today relates primarily to political science. Recognition of Soviet constitutions by the basic laws of society and their "sociologization" were not accidental. In the period of existence of the Soviet organization of power, there was a desire for the mythologization of social life. In such circumstances, the constitution was considered primarily as one of the tools of ideological influence on the internal and foreign policy environment. Moreover, the ideological function attributed to it, which, as a rule, was set at a level or even above the legal function.

It is known that any constitution plays a significant socio-regulatory function, and it is in this sense that it can be perceived as the basic law of society. However, even the most socialized constitutions are primarily the main laws of the state. Those positions that are outwardly addressed to the public are formulated in a general form, have a fragmentary appearance and, in the end, usually reflect the interaction between society and the state. Determination of the constitution as the basic law of the state does not mean the substitution of society by the state, the nationalization of social life. Such a definition testifies to the nature of civil society as such, where society and each individual are protected from the full interference of the state, and the

${ }^{19}$ О.В. Прієшкіна. Конституційний лад України та його роль у становленні та розвитку місцевого самоврядування. Інститут законодавства Верховної Ради України. Київ, 2009. Р. 122.

${ }^{20}$ В. Шаповал. Феномен конституции. Р. 4. 
latter is an integral part of the political system of society and does not absorb all its essential manifestations ${ }^{21}$.

The constitution as the basic law of the state does not create the state but only establishes the foundations of its organization. In this regard, it plays a creative role in the state mechanism, first of all, its most important links - the supreme bodies of the state. The political task of the constitution is to establish the sovereignty of the state, to consolidate the establishment or change of the state system, to ascertain the degree of continuity in the development of the state. No less important is that the constitution as the basic law of the state determines the principles in the field of relations between the state and the person. According to the historically formulated definition based on ideas of natural law, the constitution is a certain system of restrictions of state power in the form of appropriately established rights and freedoms, as well as legal guarantees for their implementation ${ }^{22}$.

The constitution in modern conditions of democratic development (that is, when we deal not with declarative constitutions of authoritarian states but with actual legal acts) becomes one of the decisive factors of social and state-legal development. In this sense, there can be no objection to the interpretation of the constitution as a source of state policy. Moreover, the constitution appears not only as one of the possible factors of influence on state policy, namely, as its fundamental basis and decisive factor, without which the democratic foundations disappear. And without a focus on democracy, it already begins to serve not the interests of society as a whole but exclusively the interests of certain clans, political groups or individual politicians ${ }^{23}$.

\section{Constitution and state policy}

Today, one of the reasons for the constant tension in relations between the supreme bodies of state power in Ukraine is the imperfection of the Basic Law, the different interpretation of its norms, as well as the fundamental change of the state policy, especially after the 2004-2005 presidential elections.

The constitution has a mixed political and legal nature, as well as to a large extent all constitutional law. Constitutional relations that arise on the basis of its provisions can also be characterized as having a dual nature: political and legal at the same time. Powerful relations subject to constitutional regulation create prerequisites for the appearance of political issues in constitutional law and politicize it to a certain extent. The political

\footnotetext{
${ }^{21}$ І. Коліушко, Ю. Кириченко. Проблеми дієвості Конституції України та удосконалення ії змісту. «Парламент» 3 (2001). Р. 14.

22 В. Шаповал. Феномен конституции. Р. 4.

${ }^{23}$ І. Гладуняк. Конституція як основа формування та реалізації державної політики. «Віче» 21-22 (2007). Р. 11-12.
} 
and legal in the constitution are closely intertwined, as well as the implementation of constitutional provisions can have a legal and political dimension.

As A. Heywood has rightly pointed out, for the vast majority of democratic states, constitutions were traditionally perceived as "precise descriptions of the current system of government" ${ }^{\text {24 }}$. Consequently, any constitution always carries a certain prognostic-axiological element, which allows foreseeing a further direction of the state development and, accordingly, state policy. It is important to note that the prognostic function of the Constitution is directly written by well-known domestic researcher Yu. Todyka ${ }^{25}$. However, we now mean not only one of the possible functions of the constitution but also the fact that at its level the values are laid down that the state is called to provide.

The authors of the monograph "Politics, Law and Power in the Context of Transformation Processes in Ukraine" characterize state policy as a "system of purposeful measures aimed at solving certain social problems, meeting public interests, ensuring the stability of the constitutional, economic, legal system of the country [...] the specificity of which is that it is realized through the power structures that have the authority of the monopoly right of the state to lawful coercion" ${ }^{26}$. Indeed, the link between the state policy and the constitution is shown by not only the reference to such a concept as "constitutional system". From the outset, the authors of the above-mentioned study establish a clear correlation between the direction of state policy and the process of ensuring social stability and satisfaction of the public interest. It should be borne in mind: the main social interests are always connected with the system of rights and freedoms of citizens of the state, which are not only formally fixed in the Constitution but must also be secured by it as a legal act of the highest legal force, which has a sign of direct imperative action (Article 8 of the Constitution of Ukraine) ${ }^{27}$.

The same can be said for a widely used in the modern Ukrainian science definition of the state policy by V. Tertychka. This author proposes to interpret the state policy in the following way: "relatively stable, organized, and purposeful activity/inactivity of state institutions, carried out by them directly or indirectly on a particular problem or a set of problems that affects the life of society" ${ }^{28}$. Moreover, justifying the appropriateness of this way of understanding the phenomenon of state policy, he notes that the definition of state policy implicitly implies that it is based on the law and must be

24 Э. Хейвуд. Политология. Москва: Юнити-Дана, 2005. Р. 359.

${ }^{25}$ Ю.Н. Тодыка. Конституция Украины. Р. 70-80.

${ }^{26}$ Політика, право і влада в контексті трансформаційних процесів в Україні, еd. I.О. Кресіної. Інститут держави і права ім. В.М. Корецького НАН України. Київ, 2006. P. 35

${ }^{27}$ І. Гладуняк. Конституці. Р. 11-12.

${ }^{28}$ Політика, право і влада в контексті трансформаційних процесів в Україні. Р. 82-83. 
legitimate. That is, state policy does not appear, so to speak, solely on its own accord and on their own will of those who are currently endowed with state power. On the contrary, in order that this direction of the state's activity should be systematic and coherent, it is necessary from the very beginning to have a certain set of rules and principles that would indicate: a) the type of political regime; b) the way of organizing state power; c) the main political institutions, the presence of which ensures the normal development of the state mechanism; d) the basic values and tasks that must be implemented during state and social development.

These rules should be fixed at the legislative level so that there are no ambiguous political interpretations of the way, in which policy should be implemented and on what grounds ${ }^{29}$. The universal method of fixing these rules and regulations is the method of constitutional determination. By giving these rules and principles an imperative value, the state acts as the guarantor of the fact that all participants in social and political relations will adhere to them. At the same time, it itself, as a mechanism of institutionalized coercion, will act in accordance with certain standards. Therefore, it is quite natural that in all democratically-operated countries, programs for the realization of state policy are always developed and implemented in accordance with the constitution.

However, it is necessary to distinguish between the constitution as a legal act and the functions specific to it in the legal field and the constitution as a political document having a certain socio-political content that directly or indirectly affects the entire political system of the country ${ }^{30}$.

Consequently, the relationship between the constitution and politics manifests itself in two main areas. First, in a broad sense, political relations are one of the most important constituent parts of constitutional regulation. Constitutional norms set legal boundaries for the political process. They consolidate the foundations of the political system of society, and not only. In modern constitutions, the foundations of the social and spiritual systems of society, which affects the expansion of the object of constitutional regulation at the turn of XX - XXI centuries, are increasingly reflected. As rightly V. Chyrkin notes, "constitutional law went beyond a largely formalized approach of the XVIII - XIX centuries and spread to the settlement of issues of the social system, the situation of one or another stratum, groups of the population (social, national, age, etc.), socio-economic rights" ${ }^{31}$.

Secondly, the constitution itself embodies a certain policy of the state, the desire of the project developers to consolidate certain principles and political

\footnotetext{
${ }^{29}$ І. Гладуняк. Конституція. Р. 11-12.

${ }^{30} \mathrm{Ibid}$

31 Б.Е. Чиркин. Об объекте конституционно-правового регулирования. Российский конституционализм: проблемы и решения: материалы международной конференции. Москва: Академия, 1999. Р. 126.
} 
values. Even K. Marx argued that "all legal has in its essence a political nature" ${ }^{32}$. This thesis on the Basic Law, according to V. Luchyn, becomes of a special significance. The political orientation of the constitution is one of the most important qualities that determine its special role in the legal system, a special social role in society. However, the idea that a constitution is created by the state to achieve a certain political goal requires some adjustments ${ }^{33}$.

From the standpoint of democratic constitutionalism and the theory of social contract, both the institutions of public authority and the electoral body participate in the act of constitution creation in one way or another. Therefore, official representatives of the state - only one of the subjects of the constitution creation. The constitution should integrate not only state goals of development but also the idea of society about the goals of social progress, to be an indicator of the needs of different social groups, the expression of their expectations and hopes ${ }^{34}$.

In the history of Ukrainian constitutionalism, the Constitution has repeatedly acted as a tool of state policy, ruling circles or political forces that came to power. Thus, the First Soviet Constitution - the Constitution of the RSFSR of 1918 - consolidated the victory of the proletariat and the poorest peasantry after the October Revolution, and was actively used by the Bolsheviks as a means of political struggle against social strata and classes that did not share the ideals of socialist construction.

Interesting is the characteristic of the Constitution of the RSFSR of 1918, given by the well-known Soviet legal ideologist of the 20's P. Stuchka to the twelfth anniversary of the revolution of the state and law. He called it "the civil war constitution”, which is largely justified since it openly supported class positions on the issue of the acquisition and implementation of basic civil and political rights and freedoms ${ }^{35}$. Later in the process of constitutional development of the Soviet state, constitutional right gradually cleared itself from the ability to act as a tool of class domination, acquiring the nature of a universal legal regulator ${ }^{36}$.

In the mid-80's, political scientist I. Stepanov, reflecting on the relationship between the constitution and politics, expressed the view that politics and law should be represented in the constitution in an organically integral form, "balanced in a coherent unity" ${ }^{37}$. Of course, during the Soviet

${ }^{32}$ К. Маркс, Ф. Энгельс. Сочинения, 2-е изд. Vol. I. Москва: Политиздат, 1991. Р. 635.

33 В.О. Лучин. Конституционные нормы и правоотношения: учебное пособие [для вузов]. Москва: Эксмо, 1997. Р. 33-34.

${ }^{34}$ І. Гладуняк. Конституція. Р. 11-12.

35 П.И. Стучка. Двенадцать лет революции государства и права, «Революция права» 6 (1929). Р. 10.

${ }^{36}$ І. Гладуняк. Конституція. Р. 11-12.

${ }^{37}$ И.М. Степанов. Конституция и политика. Р. 24. 
period, the study of the constitutional policy was limited by many partyideological barriers. However, the search for an optimal combination of politics and law in the constitution, constitutional policy, and political law is an important and constantly restored process of democratic development.

On the one hand, the tradition of observing constitutional limitations by subjects of political activity and political relations should be developed. On the other hand, the constitutional law should not be disconnected from political issues, and constitutionalists should seek to see political aspects in the implementation of constitutional norms. The study of political issues in constitutional law can shed light on the motives for adopting the constitution as a whole or individual constitutional changes, it can serve as an explanation or justification for the constitutionally regulated actions of state bodies and officials. In general, political issues highlight the controversial and problem areas of constitutional and legal development, contribute to the formation of a constitutional paradigm within the legally established normative framework of relations of person, society, and state ${ }^{38}$.

In the concept of a political constitution, a special vision of a political community is laid down, in which a coordinated interaction between citizens and authorities is ensured and a political agreement on rules of conduct in the political sphere is taking place. History gives a lot of examples of violent imposing of the constitution by the ruling party, the authoritarian head of state, the oligarchic or military regime. However, in the spirit of the democratic policy, a constitution as a political document cannot be a political pact, which reflects the search for public consent and compromise in resolving various political and social conflicts ${ }^{39}$.

In the political sphere, functions of the constitution are inextricably linked with its nature. In many respects, its effectiveness in the field of politics depends on the nature of the constitution. After all, the nature of the constitution is its socio-political content. In the national political science, in the Soviet era, the class nature of the constitution and its content were distinguished. Under class nature, they understood the basic socio-political characteristics of the constitution. It finds its manifestation in its content, principles, properties, and functions, has a decisive influence on its form, defining its fundamental features. The content of the constitution is the specification of its class nature. Moreover, the content may vary within a specific nature under the influence of a number of objective and subjective factors. The constitution had a dual meaning - social and legal ${ }^{40}$. The point is

38 И.А. Кравец. Сущность конституций и конституционный процесс (динамика социально-политического содержания российских конституций). Весник Московского гос. ун-та. 4 (2003). Р. 35.

${ }^{39}$ І. Гладуняк. Конституція. Р. 11-12.

40 Ю.Л. Юдин. Конституции, in: Конституционное право развивающихся стран: предмет, наука, источники, еd. В.Е. Чиркин. Москва: Юридическая литература, 1987. Р. 39. 12 
that this approach was based on a formative theory, according to which the specifics of the nature of the constitution in different countries were tied to a certain socio-economic formation. Throughout the period of the development of Soviet constitutions, even in the late period, known as "developed socialism", dominated the class concept of the nature of the constitution, which was determined by the class (classes) it serves and which type of property it establishes ${ }^{41}$.

In our opinion, the nature of the constitution derives from its sociopolitical content, so to speak, in a concentrated form. The legal content of the constitution is determined by the objects of constitutional regulation, in other words, what legal institutes, principles, and provisions are reflected in the text of the constitution and in this regard acquire the constitutional status. Given the differences in the legal and socio-political content of the constitution, it is necessary to identify the key elements of its nature, which have a political influence on the functioning of constitutional provisions.

These elements can be formulated in the form of theoretical postulates, the answers to which give a general idea of the nature of a specific constitution. These include:

1) the will of which political forces found a consolidation in constitutional provisions (whose political will was enshrined in the constitution?);

2) the interests of which social strata are reflected in the constitutional provisions and supported by them (whose interests are reflected and supported by the constitution?);

3) what is the degree of legitimacy of the constitution, which is largely determined by the terms of its project development and the procedure for its adoption (how the chosen procedure for the development and adoption of the constitution influenced the degree of its legitimacy?).

In specific historical conditions and the legal culture of an individual country, the answers to these questions may vary. In the constitutional history of one and the same country, different constitutions may have a different essence. Moreover, the essence of one and the same constitution can eventually be transformed and move away from the original idea of its creators. This is primarily related to the fact that the socio-political conditions of the constitution, the implementation of its provisions can change.

${ }^{41}$ Н.П. Фарберов. Новая Конституция СССР - манифест эпохи строительства коммунизма, in: Н.П. Фарберов. Конституция развитого социализма. Москва: Восход-А, 1979. P. 68. 


\section{CONCLUSIONS}

Consequently, the main and still unresolved issue is the ambiguity of what is proposed to adopt: a new Constitution, a new version of the current Constitution, amendments and additions to the current Constitution. Although paradoxical, but in Presidential speeches, these terms are used repeatedly as synonyms. However, legally they are completely different concepts. This terminological confusion carries a great danger of loss of landmarks and prevents a clear statement of the problem in a purely legal area.

Thus, we believe that the constitutional process is too politicized today. In our opinion, the acutest political struggle is underway for adopting a form of constitution that is convenient for one of the parties. But in fact - for power - everyone wants a maximum of power. Including through their Constitution enforced in some way. However, the Basic Law should be adopted not from the conjuncture considerations of political expediency, but be a complete legal document, taking into account the achievements of the world jurisprudence, with the strict observance of all the prescribed legal procedures. After all, the constitution should be the main document of the state, at least for a decade.

\section{SUMMARY}

The scientific publication is devoted to highlighting the peculiarities of the legal nature of the constitution. The authors consider the structure and content of the constitution of the state in the context of its functions. The specificity of the content of the newest constitutions in the history of world constitutionalism is considered. The correlation between the constitution and the state policy is established. Modern approaches to understanding the nature of the constitution are considered. The legal nature of the Constitution of Ukraine is determined.

\section{REFERENCES}

1. Bielov, Dmytro M. 2010. "Struktura ta zmist konstitucii: okremi aspekti.” Naukovijj visnik Uzhgorodskogo nacionalnogo universitetu. Seria Pravo 14(1):80-87.

2. Chyrkin, B.E. 1999. Ob obekte konstitucionno-pravovogo regulirovanija. Rossijjskijj konstitucionalizm: problemy i reshenija: materiały mezhudunarodnojj konferencii. Moskva: Akademija.

3. Cippelius, Rajjngold. 2000. Filosofija prava. Kiev: Tandem.

4. Eremenko, Yurij P. 1982. Sovetskaja Konstitucija i zakonnst. Saratov: Izd-vo SGU.

5. Farberov, N. P. 1979. "Novaja Konstitucija SSSR - manifest ehpokhi stroitelstva kommunizma." In N.P. Farberov, Konstitucija razvitogo socializma, 67-81. Moskva: Voskhod-A. 
6. Galkin, Aleksandr A., and Yurij Krasin. 1995. Rossija na perepute: avtoritarizm i demokratija: varianty razvitija. Juridicheskaja literatura.

7. Gladunjak, Ivan. 2007. "Konstitucija jak osnova fotmuvannja ta realizacii derzhavnoi politiki.” Viche 21-22:11-12.

8. Khejjvud, Eh. 2005. Politologija. Moskva: Juniti-Dana.

9. Koliushko Igor, and Yurij Kirichenko. 2001. "Problemi dievosti Konstitucii Ukrajini ta udoskonalennja ii zmistu.” Parlament 3:12-15.

10. Kozlova, Ekaterina I., and Oleg Kutafin. 2003. Konstitutsionnoe pravo Rossii. Moskva: Jurist.

11. Kravec, Igor A. 2003. "Suchhnost konstitucijj i konstitucionnyjj process (dinamika socialno-politicheskogo soderzhanija rossijjskikh konstitucijj).” Vesnik Moskovskogo 4:34-39.

12. Kresinoi, Irina O. (edited by). 2006. Politika, pravo i vlada v konteksti transformacijjnikh procesiv $\mathrm{v}$ Ukraini. Kiev: Institut derzhavi i prava im. V.M. Koreckogo NAN Ukraini.

13. Lenin, Vladimir I. 1980. Polnoe sobranie sochinenijj. Vol. XXXVI. Moskva: Politizdat.

14. Luchin, Viktor O. 1997. Konstitucionnye normy i pravootnoshenija: uchebnoe posobie [dla vuzov]. Moskva: Ehksmo.

15. Luchin, Viktor O. 2002. Konstitutsiya Rossijskoj Federatsii. Problemy realizatsii. Moskva: Juniti-Dana.

16. Lukjanova, Elena A. 2001. "Znachenie Konstitucii SSSR 1977 g. v razvitii istochnikov rossijjskogo gosudarstvennogo prava.” Gosudarstvo i pravo 4:22-27.

17. Marks, Karol, and Fridrich Engels. 1991. Sochinenija. Vol. I. Moskva: Politizdat.

18. Onishhenko, Olga V. 2005. Konstitucija Ukraini jak osnovne dzherelo konstitucijjnogo prava Ukraini. Kiev: Konsum.

19. Opryshko, Vitalijj F. 2000. Konstitucija Ukraini - osnova sistemi nacionalnogo zakonodavstva. Kiev: Vidavnichijj Dim «Juridichna Kniga».

20. Prieshkina, Olga V. 2009. Konstitucijjnijj lad Ukraini ta jogo rol u stanovlenni ta rozkvitu miscevogo samovrjaduvannja. Kiev: Institut zakonodavstva Verkhovnoi Radi Ukraini.

21. Redlich, Norman, Bernard Schwartz, and John Attanasio. 1995. Understanding Constitutional Law. Irwin: Matthew Bender.

22. Reiman, Jeffrey. 1988. "The Constitution, Rights, the Conditions of Legitimacy.” In Constitutionalism: The Philosophical Dimension, edited by Alan S. Rosenbaum, 132-139. New York: Greenwood Press.

23. Sajó, András. 1999. Limiting Government. An Introduction to Constitutionalism, Budapest: Central European University Press.

24. Salygin, Evgenijj N. 1999. Teokraticheskoe gosudarstvo. Moskva: Juridicheskaja literatura. 
25. Savchyn, Michael B. 2009. Konstitucionalizm i priroda konstitucii. Monografija. Uzhgorod: Poligrafcentr «Lira».

26. Selivanov, Volodimir. 2002. Pravo i vlada suverennoi Ukraini: metodologichni aspekti. Kiev: Juridichna dumka.

27. Shapoval V. M. 1997. Konstituciyne pravo zarubizhnih krayin: Pidruchnik. Kiev: ArtEk Vishha shk.

28. Shapoval, Vladimir. 2008. "Fenomen konstitutsii v kontekste otechestvennoy politiko-pravovoy «mifilologii».” Zerkalo nedeli 9 August, 29:4.

29. Shevchuk, Stanislav. 2002. Osnovi konstitucijjnoi jurisprudencii. Navch. posibnik. Kharkiv: Konsum.

30. Sjukijajjnen, Leonid R. 1986. Musulmanskoe pravo: voprosy teorii i praktiki. Moskva: Nauka.

31. Sjukijajjnen, Leonid R. 1997. Shariat i musulmansko-pravovaja kultura. Moskva: Armada.

32. Stecjuk, Petro B. 2004. Osnovy teorii konstytucji ta konstytucjonalizmu. Chastyna persha: posibnyk dlja studentiv. Lviv: Astroljabija.

33. Stepanov, Igor M. 1984. Konstitucija i politika. Moskva: Izd-vo Nauka.

34. Stuchka, Petr I. 1929. "Dvenadcat let revoljucii gosudarstva i prava”. Revoljucija prava 6:56-61.

35. Todyka, Yurij N. 2000. Konstitucija Ukrainy: problemy teorii i praktiki. Kharkiv: Fakt.

36. Tyhomyrov, Yurij A., and I. V. Kotelevskaya. 1999. Pravovye akty: uchebnoprakticheskoe i spravochnoe posobie. Moskva: Jurinformcentr.

37. Yudin, Yurij L. 1987. "Konstitucii." In Konstitucionnoe pravo razvivajushhikhsja stran: predmet, nauka, istochniki, edited by Veniamin E. Chirkin, 38-42. Moskva: Juridicheskaja literatura.

\section{Information about the author:}

Bielov D. M.,

Doctor of Laws, Professor, Professor at the Department of Constitutional and Comparative Law,

Uzhgorod National University

26, Kapitulna str., Uzhgorod, 88000, Ukraine 